\title{
Baudelaire journaliste. Articles et chroniques, choix de textes, présentation, notes, chronologie, bibliographie et index par Alain Vaillant
}

\section{Ida Merello}

\section{(2) OpenEdition}

\section{Edizione digitale}

URL: http://journals.openedition.org/studifrancesi/5714

DOI: $10.4000 /$ studifrancesi. 5714

ISSN: 2421-5856

\section{Editore}

Rosenberg \& Sellier

\section{Edizione cartacea}

Data di pubblicazione: 1 septembre 2011

Paginazione: 443

ISSN: 0039-2944

\section{Notizia bibliografica digitale}

Ida Merello, «Baudelaire journaliste. Articles et chroniques, choix de textes, présentation, notes,

chronologie, bibliographie et index par Alain Vaillant», Studi Francesi [Online], 164 (LV | II) | 2011, online dal 30 novembre 2015, consultato il 13 janvier 2021. URL: http://journals.openedition.org/ studifrancesi/5714 ; DOI: https://doi.org/10.4000/studifrancesi.5714

Questo documento è stato generato automaticamente il 13 janvier 2021.

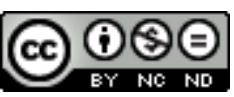

Studi Francesi è distribuita con Licenza Creative Commons Attribuzione - Non commerciale - Non opere derivate 4.0 Internazionale. 


\title{
Baudelaire journaliste. Articles et chroniques, choix de textes, présentation, notes, chronologie, bibliographie et index par Alain Vaillant
}

\author{
Ida Merello
}

\section{NOTIZIA}

Baudelaire journaliste. Articles et chroniques, choix de textes, présentation, notes, chronologie, bibliographie et index par Alain VAILlANT, Paris, Garnier Flammarion 2011, $381 \mathrm{pp}$.

Per comprendere il rapporto di Baudelaire con la stampa, Alain VAILLANT procede innanzitutto a una rigorosa contestualizzazione storica, ricordando il ruolo di riviste e quotidiani nella diffusione letteraria, prima della massiccia affermazione dell'editoria avvenuta durante il Secondo Impero. È infatti grazie alla visione culturale comune anche ai giornali di grande diffusione che un ampio ventaglio di pubblicazioni periodiche ha ospitato non solo gli interventi saggistici e d'occasione del poeta, ma anche, com'è noto, le sue opere propriamente letterarie, compresa una scelta delle Fleurs. La difficoltà di governare un materiale vastissimo viene risolta grazie a una cronologia finale che rende conto di tutti i pezzi pubblicati da Baudelaire; mentre il curatore si riserva il compito di una selezione che risponda al doppio criterio di proporre testi meno universalmente conosciuti, ma ugualmente rappresentativi e tali da render conto di un'evoluzione teorica e politica. In tal modo attraverso la sua scelta si segue bene il percorso da una prima fase scherzosa ed ironica (ad es. Comment on paie ses dettes, quand on a du génie; choix de maximes consolantes sur l'amour) a una in cui si 
manifesta l'illusione di un rinnovamento politico (Vive la République ecc.), fino all'elaborazione sempre più attenta di un'estetica. 